\title{
Leprosy in East and Central Africa.
}

\section{R. G. Cochrane.}

(1) Egypt and the Anglo-Egyptian Sudan.

$\mathrm{T}$ is proposed in this series of articles to review the situation in the territories recently visited by the Secretary of the - Association. Most of the material is gathered from the reports which were furnished from time to time. In this first instalment the position in Egypt and the Anglo-Egyptian Sudan will be considered.

Egypt all down the ages has taken a prominent place in the destiny of north and central Africa. This land of romance and antiquity has many difficult problems to face, and the least of them is not leprosy. Leprosy has been known in Egypt for very many centuries. There is an old Egyptian record of about 1350 B.C., which refers to leprosy among negro slaves from the Sudan and Darfur. This is interesting in view of the present high rate and type of leprosy seen in the Bahr-el-Ghazal province bordering Darfur. Lucretius in his "de Natura Rerum" makes reference to the origin of the disease in the following lines:-

"High up the Nile midst Egypt's central plane, Springs the dread leprosy and there alone."

It is evident then, that leprosy has been known in Egypt for many centuries, but until recently, apart from the segregation of a few advanced cases little was done for the unfortunate sufferers. For some years now the Church Missionary Society at Old Cairo has been doing what they could to treat the lepers which presented themselves for treatment at the hospital.

In 1928, the Egyptian Government took an active part in the organisation of anti-leprosy schemes. In this year a doctor was sent to India and the Philippine Islands for training and on his return was put in charge of the organisation of a complete system for the combating of leprosy in the country. Within a short time of his return, Dr. Dalgamoni organised an out-patient centre in Old Cairo. A philanthropically minded citizen gave a house in this part of the city for the purpose. This has been adapted in an admirable way, the old courtyard making an ideal place for the assembling of the patients. At the time of visiting this dispensary, some 300 patients were on the roll. Many of these were unfortunately advanced skin cases, but an encouraging feature is the increasing number of earlier cases coming forward, and one hopes that once this centre has been 
established and prejudice broken down, a still greater number of early cases will present themselves for treatment.

The leprosy section of the Department of Public Health has under consideration a complete scheme for dealing with leprosy; it includes :-

1.- The establishment of three out-patient clinics, one in Egypt, and another to be established in Upper Egypt.

2.-The establishment of a leper colony about twenty miles from Cairo, ultimately to accommodate one thousand patients.

3.--The sending of another doctor to the Philippines and India for a period of training so that he can assist the leprosy expert in the organisation and running of the anti-leprosy work.

It has been suggested that the above proposals should incorporate a scheme for the training of medical students and practitioners in the diagnosis and treatment of the disease, that the leper colony should be a centre for clinical training and research and that the out-patient clinics also should be used for these purposes.

It is the intention of Government to pass a law for the compulsory segregation of all infective cases when the settlement has been completed. It has been brought to the notice of the authorities that while for those cases which were infective and could not, or would not, look after themselves, a law such as this, in a country like Egypt, was useful, yet it should be borne in mind that unless carefully supervised such a law might not produce the results intended, and cause the concealment of cases. There is no doubt that the Government are fully alive to the dangers of any parliamentary measures and it is not intended to bring in a general measure of compulsion.

In a civilised country such as Egypt, there should be little difficulty in instituting measures which will ultimately bring this scourge under control.

\section{The Anglo-Egyptian Sudan.}

The Anglo-Egyptian Sudan is not far short in area of the whole of British India, and has a population of $6,469,041$ (1928). This comparison gives one some idea of the difficulty of administration and more particularly the difficulty of medical relief in the African territories. The medical problems of the Sudan are very similar to those of Egypt, and the endemic diseases of the two territories are of the same 
nature. Leprosy, however, as far as is at present known, seems to be largely confined to the southern provinces. In Omdurman, the old Dervish capital, there is a leper home under the supervision of the Church Missionary Society. When the Secretary visited this hospital, there were some forty inmates, most of whom were very advanced cases. In addition to this institution for lepers the C.M.S. conduct a centre in connection with their hospital in Omdurman. Some eighteen cases were attending at the time of the visit, among these being quite a number of patients in the earlier stages of the disease. Apart from this centre, there is no work organised in northern and central Sudan, and according to present knowledge, there is little need of it. Owing to climatic conditions, northern Sudan probably has practically no leprosy, as this area is within the desert belt. In central Sudan, the incidence of leprosy has not been determined; there is a certain amount of evidence that the tribes in the Nuba Mountains are affected but to what extent is unknown. Most of the tribes in this area are warlike, and tend to be troublesome, and therefore until they have been brought under discipline to a greater extent, it would be very difficult to organise " anti-leprosy" work and still harder to attempt anything in the way of a survey. There is a certain amount of evidence that leprosy may be spreading from foci into Central Sudan, especially in Mongalla, but definite information is lacking. With the opening up of communications, and the pacification of the tribes, any tendency to spread, one fears, will be accelerated.

In the southern provinces of Mongalla and Bahr-elGhazal the incidence of leprosy is extremely high. The number of lepers in the Sudan has been estimated at 6,000, but there are over 5,000 segregated in these provinces alone, and therefore, there must be a considerable number over this figure in the whole territory. It is in Bahr-el-Ghazal and Mongalla, that the Sudan Government have undertaken anti-leprosy measures on a large scale. The situation in these two provinces is entirely different. In Bahr-el-Ghazal, whatever the reason-probably the disease is of an older origin, or the people are more healthy-leprosy is of a comparatively mild type, whereas in Mongalla the disease, especially in the Meridi and Amadi districts (see map), is of a much more severe type. In the course of these summaries I shall be referring again to the importance of estimating the type and infectivity of the disease when considering anti-leprosy measures. In the province of Bahr-el-Ghazal there are three leper camps, viz., Wau, Yubo and Yambio. The policy of 
Sketch Map of Egypt and Anglo-Egyptian Sudan, showing Main Leper Centres and Stations Visited by Secretary on Recent Tour.

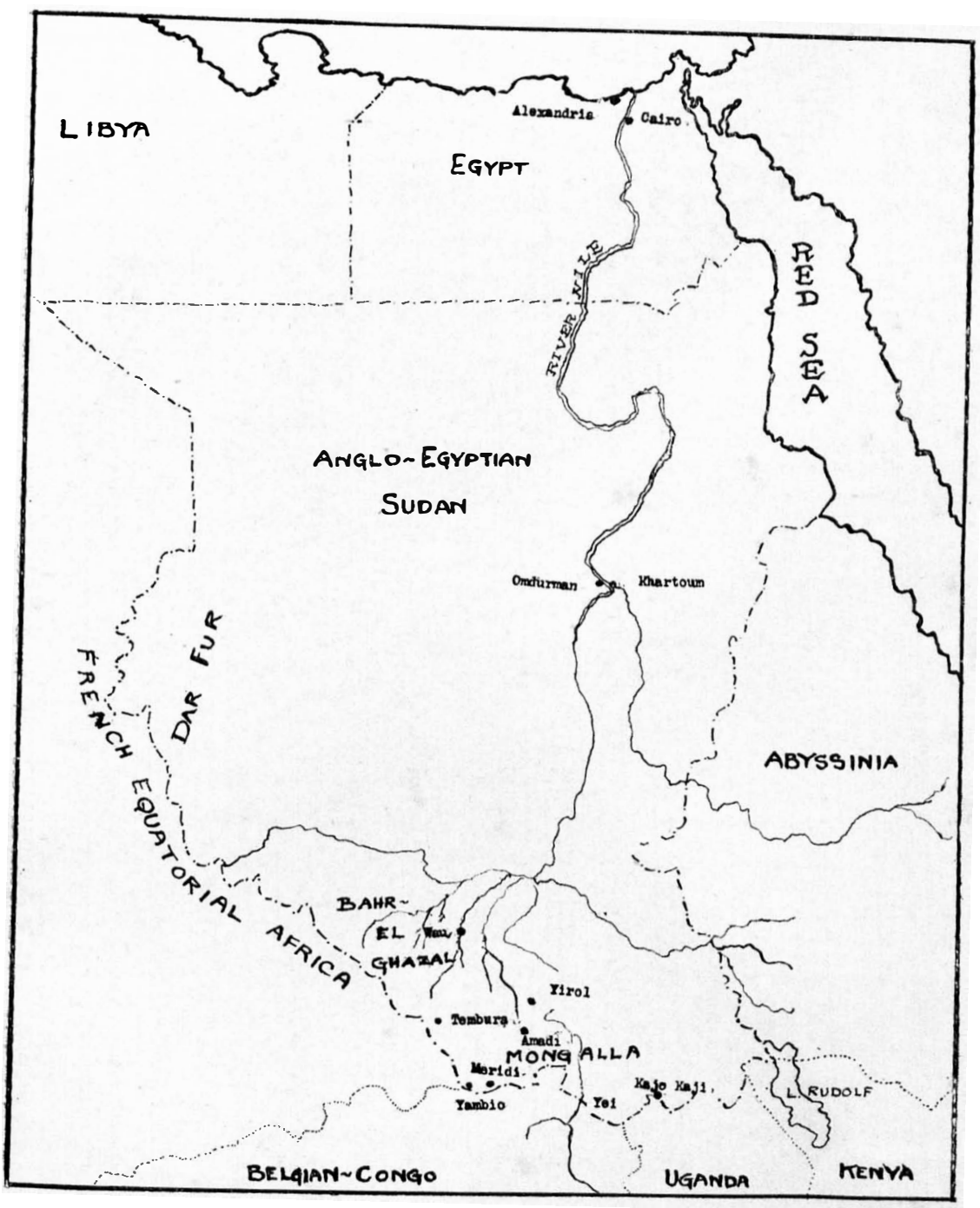




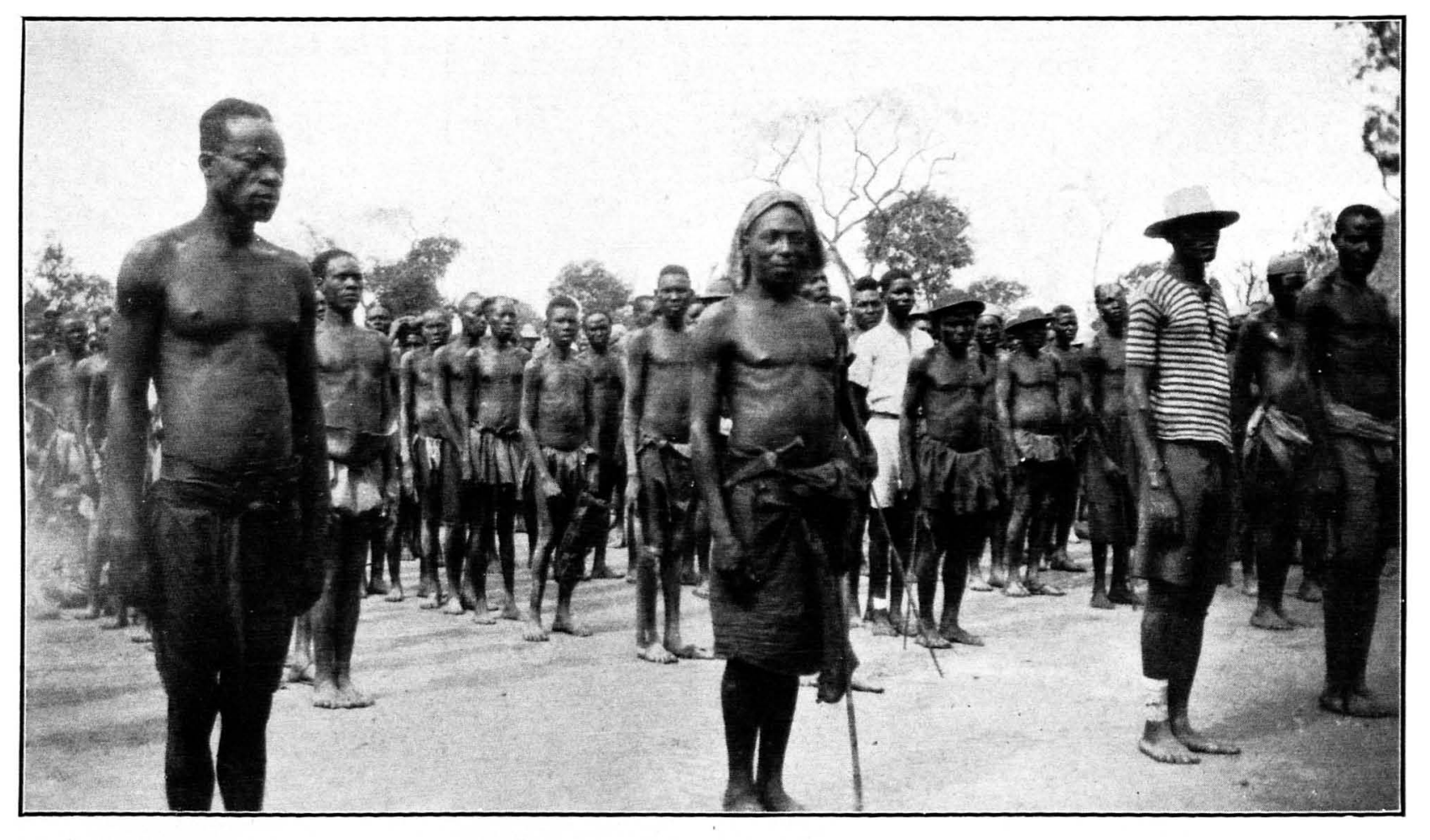


the Government in this province is the provision of large settlements for lepers, where not only the actual cases but their families can live. They live in such a way that, as far as food is concerned, they become self-supporting in a short time. In a word, these settlements are in reality large outpatient centres where patients, instead of being scattered in inaccessible villages, are brought within one definite administrative area. This involves no hardship as the native huts are easily erected and therefore villages can readily be moved into more convenient areas for purposes of control. From their villages, which have been organised under supervision, the patients proceed to the central hospital and treatment station for injections and examination.

The area affected with leprosy is chiefly that occupied by the Zande tribe or the Niam Niam, the latter name being supposed to represent the noise that the tribe made when eating human flesh. These people, however, are now peace loving, cheerful, and amenable to discipline, so much so that the method described for controlling leprosy is eminently successful. Every leper is known and very shortly it is hoped that practically all the treatable and infective cases will have been segregated in the large areas provided for this purpose. It is therefore within the bounds of possibility that leprosy will be eradicated from this part of the Sudan within a few decades.

In the Mongalla Province there are four leper camps and settlements, and another one is being planned. The three existent centres are at Meridi, Lui (Amadi), Yei and Kajo-Kaji. At Lui, Dr. Fraser of the C.M.S., is in charge. Dr. Fraser is working among the Moro tribe and has plans for the extension of this camp. This is run on Mission lines, and the sexes are separated. I was struck by the large number of infective cases in this colony. The type of case seen indicates that either the disease is comparatively new in the district, or else for some reason the virulence has increased. The disease has probably spread from the Belgian Congo, and while there are indications that it is still spreading in the Bahr-el-Ghazal province, one would conclude that the danger of spread in Mongalla is greater.

The work at Lui has so far catered practically solely for the Moro tribe, but as the Bari tribe in the immediate neighbourhood are heavily infected with the disease it is hoped that the work will be extended so as to meet this situation. In addition it is the intention of the Government to organise another settlement near Juba to meet the needs of the district further south. 
There are two other colonies in Mongalla, the first is at Yei about 30 miles from the Belgian Congo, and the second is at Kajo Kaji, near to the Uganda border. The settlement at Yei is run along lines similar to those in the Bahr-elGhazal and within a short time it is expected that all treatable and infective lepers in the district will have been brought under isolation.

There is a good deal of evidence that leprosy has been or is spreading from the large foci in Mongalla to the Upper Nile Province. Work has been started by the C.M.S. at Yirrol with a view to try and cope with the situation in that district.

It is of utmost importance that leprosy should be controlled in Mongalla for with the increasing facilities for rapid communications the disease is spreading to other areas. On account of the efficient organisation and the disciplined nature of the tribes in the southernmost provinces of the Sudan it is not too much to expect that such a menace will be largely averted, and that the present foci from which leprosy is tending to spread will be abolished. 